\title{
Landscape Architecture and green spaces in Russia
}

\author{
Valery Telichenko ${ }^{1}$, Andrey Benuzh ${ }^{1 *}$ and Ilya Mochalov ${ }^{2}$ \\ ${ }^{1}$ Moscow State University of Civil Engineering (National Research University), 26, Yaroslavskoe \\ Sh., Moscow, 129337, Russian Federation \\ ${ }^{2}$ Chairman of the Board of ROO "Moscow Association Landscape architects ", 129594, Moscow, \\ Sheremetyevskaya St., 34
}

\begin{abstract}
The article considers the challenges of designing sustainable landscape architectural projects in Russian cities such as high-raised linear parks and green roofs. Sustainable landscape projects create great and green cities where the built and the natural environments are interwoven. Sometimes creating green spaces is considered as a great challenge, particularly in the big and dense cities, where there is pressure for space and green development is very limited. In this case high-raised parks and green roofs could be the only solution.
\end{abstract}

\section{Introduction}

Sustainable landscape architectural projects create ecological designs for the outdoor and urban environment. It begins with appropriate systems which address function, cost, energy efficiency, beauty and the environment. Broadly speaking, sustainable landscape architecture is the integration of ecological, social, cultural and economic factors in designing landscapes to help protect natural habitats, contribute to stormwater management, conserve water, among the other objectives.

Sustainability and conservation landscaping both strive to work with nature to reduce air pollution, increase water quality, lower water consumption, utilize native plants, and reduce usage of pest control. However, sustainability and conservation differ in the emphasis sustainability places on addressing social and economic factors in addition to environmental factors. In other words, conservation can be seen as the environmental part of the sustainability concept.

The Sustainable Sites Initiative grew out of a conference hosted in 2005 by the American Society of Landscape Architects (ASLA) and the Lady Bird Johnson Wildflower Center. The initiative's definition of sustainability derives from the well-known Brundtland report. To be sustainable, a site has to have "design, construction, operations, and maintenance practices that meet the needs of the present without compromising the ability of future generations to meet their own needs." Sustainable sites do not only mitigate negative impacts on the environment, but are a mutual benefit to the site itself and the people who use it. In addition, a sustainable site must address social, environmental, and

* Corresponding author: ABenuzh@gmail.com 
economic concerns. The economic aspects addressed must take into account the value of the natural systems of the site [1]. This is the root of the program's ecosystems services framework. In other words, the guidelines have been built around the concept that people receive benefits, in the form of goods and services from healthy ecosystems.

\section{Sustainable cities and green spaces}

170 Green open spaces are an important part of sustainable cities. Cities are comprised of more than just buildings and people. The most "liveable" cities - and some of the world's most famous cities - are as known for their open spaces as they are for their culture. Hyde Park in London, Central Park in New York, the Bukit Timah Nature Preserve in Singapore, Phoenix Park in Dublin - all are attractions in their own right for inhabitants and visitors alike and even landmarks.

Open space in urban environments provides many advantages: formal and informal sport and recreation, preservation of natural environments, provision of green space and even urban storm water management. Thus green space must be a key consideration in urban planning if the health of a city and its people are both considered important [2]. A new, broader view of parks has also recently been emerging. This new view focuses on how policymakers, practitioners, and the public can begin to think about parks as valuable contributors to larger urban policy objectives, such as job opportunities, youth development, public health, and community building.

As the world's cities continue to grow, continuing to value green space in cities is vital: but is also a challenge, particularly in developing countries where there is pressure for space, resources and development.

Urban green spaces are considered as important contributor and can be a significant part of sustainable development. Developments of urban green spaces need to consider interdisciplinary and integrative approaches such as economic, social, cultural, management and planning aspects to improve existing urban spaces' facilities and services and to optimize urban green space policies. The quality of cities depends on how the urban green spaces are designed, managed and protected. The social aspects of urban green spaces include diversity of land uses, contribution to health and active life styles in cities, social justice by incorporating all groups and ages of people into green spaces, opportunities to interact and expand social network, enhancement of cultural life for different communities living in the city by providing a platform to share views, feelings and to celebrate different groups occasions and, a venue for environmental education for the schoolchildren and a play ground for children for the social, mental and physical development [3].

From the planning aspects, urban green spaces include business, retail, leisure development, tourism development; employment centers besides residential areas and the good planning of urban green spaces can play a role as a visual screen, a function of noise protection and a place for commuting and recreation by providing well-designed networks within the park and with the other areas.

The economic aspects of urban green spaces incorporate- as a place for production and supply of fruits, wood to green business centers, and as a place for new jobs creation and increasing economic value of the area by integrating the environment friendly behavior and attracting tourists provided with convenient atmosphere, security and facilities for the tourists. Most importantly the ecological perspective considers urban green spaces as a facilitator to reduce the impact of human activities through absorbing pollutants and releasing oxygen, contributing to the maintenance of a healthy urban environment with clean air, water and soil and preserving the local natural and cultural heritage with a diversity of urban wildlife and urban resources [4]. 


\section{High-raised linear parks as a part of modern urban green city system}

Traditional urban parks are public spaces designed for either passive recreation - users sit to read, to eat, to watch other people or active facilities such as sports. These parks are destinations in itself, places to go to. In contrast, urban linear parks take you somewhere, in some cases from one transportation hub to another. They are mostly facilities for active recreation, for walking, jogging, or biking. They are "transit spaces, as they combine elements of transportation together with recreation.

Linear parks in cities and towns are popular partly because they contribute to today's interest in physical fitness. They offer urban populations changing vistas, including riversides, ports and cityscapes. They draw consumers to commercial places they might otherwise not visit. They increase residential real estate values, attracting new tenants and owners to homes and apartments with these nearby amenities.

They are remarkably diverse. Some pass through old railroad tunnels; one is being constructed on a disused elevated railway; many follow old canal berms. There are oceanside linear parks as well as riverside examples. Many transform deteriorated industrial and residential areas into popular features of the urban renaissance. Some are at least a hundred years old, while some impressive ones have been created in the past decade. They are a very active part of any city green infrastructure, connecting not only the hubs, but being a city "green veins", with a very active "green blood" flow [5].

Several recent examples illustrate quite well how these convenient and poplar public spaces have been created and the benefits they bring to urban populations.

\subsection{High Line Park, New York City}

A pair of Urban Linear Parks in Lower Manhattan combine a remarkable feature-reuse of an old elevated freight line 30 feet above the street-parallel to a second urban trail passing along the Hudson from the Battery to the Javits Center in Mid-town. The elevated High Line offers an elevated garden as well as a trail. The views and the variety of recreational offerings on the adjacent Hudson River piers - everything from a full soccer field to boating - already makes this partially completed public space among the city's most popular. A rare feature among Urban Linear Parks, this pair will provide a round trip experience for city hikers (Figure 1).

The High Line design is a collaboration between James Corner Field Operations (Project Lead), Diller Scofidio + Renfro, and Piet Oudolf. Converting each section of the High Line from an out-of-use railroad trestle to a public landscape entailed not only years of planning, community input, and work by some of the city's most inventive designers, but also more than two years of construction per section.

The High Line's planting design is inspired by the self-seeded landscape that grew on the out-of-use elevated rail tracks during the 25 years after trains stopped running. The species of perennials, grasses, shrubs and trees were chosen for their hardiness, sustainability, and textural and color variation, with a focus on native species. Many of the species that originally grew on the High Line's rail bed are incorporated into the park's landscape. The conditions of the plants in 2017 are perfect - planted species are very well developed and established and the new species are appearing by being seeded by birds. 


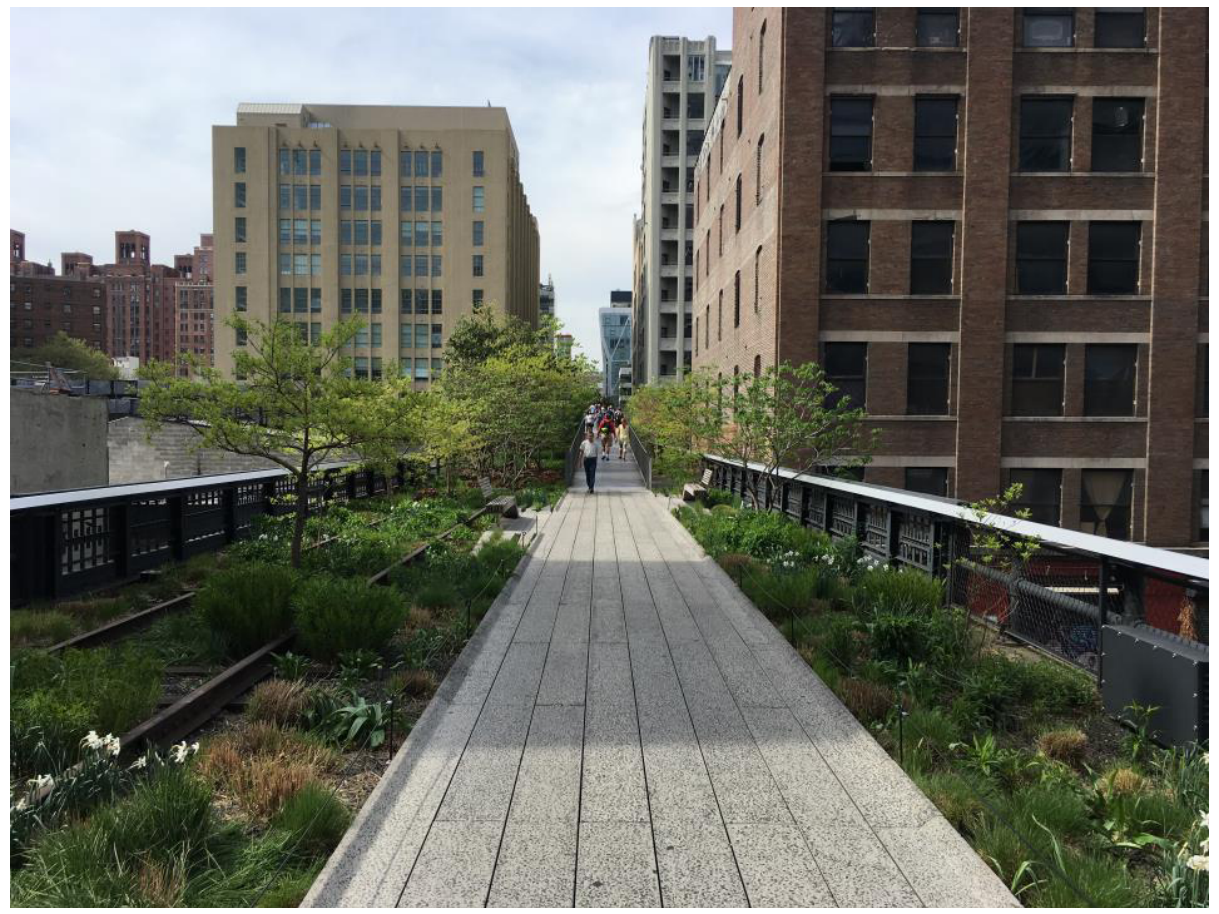

Fig. 1. High Line Park, New York City.

\subsection{Jardins de la rambla de sants', Barcelona, Spain}

Jardins de la rambla de sants' is an elevated 20,000 square meter park that opened earlier this year in Barcelona. Rather than similar designs in New York, Barcelona's elevated 'rambla' does not take the place of the rail line, but instead hides it with an extruded box that contains over 160 trees and 85,000 plants and shrubs organized into different gardens.

A structural system of beams infilled with glazing supports the park, while allowing pedestrians at ground level views of the passing trains. At certain points, the structure soars 12 meters above street level. Over 650 meters of climbing plants have already started to ascend the concrete structure, blending the natural aspects of the scheme with the built environment.

Visitors enter the park at plaza de sants, where the scheme starts to slope upwards, offering elevated views across the city. The promenade, which measures a total of 760 meters, has been designed by architects Sergi Godia and Ana Molino and hosts a range of different public amenities. Completed after a decade of development, the park is situated on a raised structure that covers existing railway lines below. Plants are recently planted, it is essential to use an automatic water irrigation due to a very harsh weather conditions.

\subsection{Skygarden in Seoul}

The Skygarden aims to regenerate and connect places near the main railway station that have been fragmented by roads and railway tracks. 


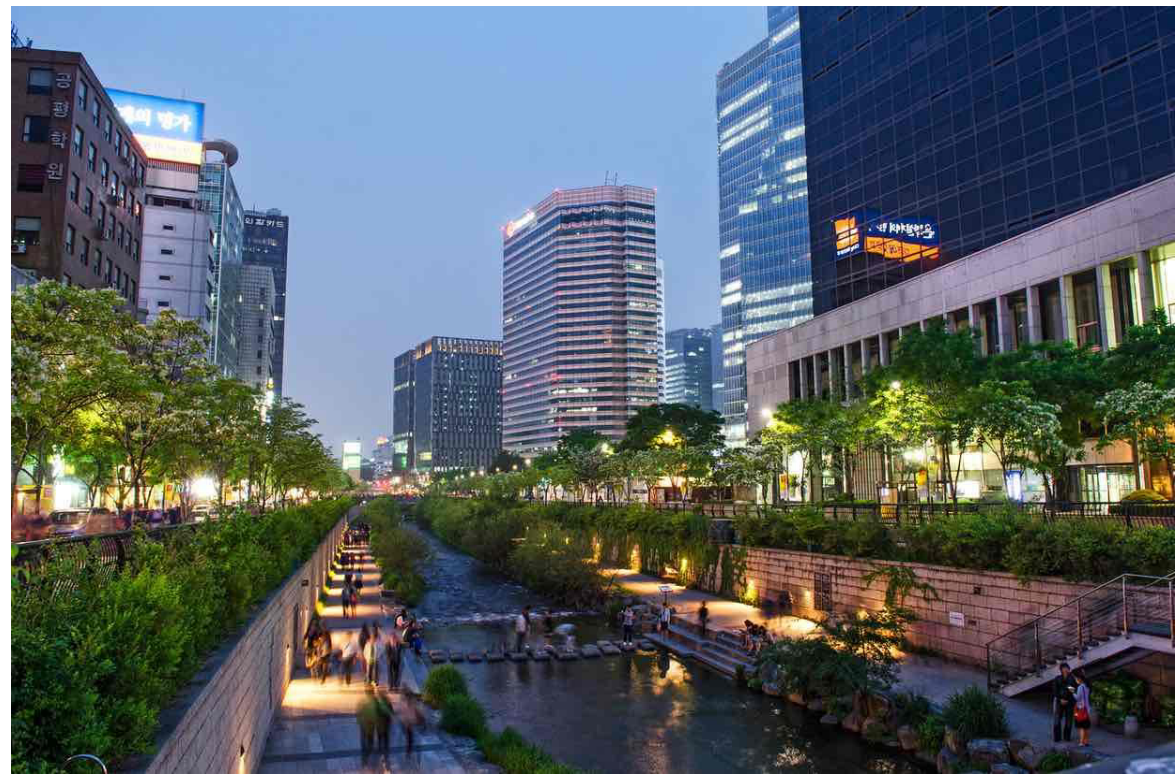

Fig. 2. Skygarden in Seoul.

The Skygarden, which will be open to all 24 hours a day, re-uses an existing structure like the High Line - in the form of a 1970 motorway flyover that was no longer deemed safe for its original purpose.

It is also part of a bigger set of ideas about taking a big, dense - sometimes ugly - city, one which was created without a great deal of concern for public space and pedestrian movement, and giving it qualities of walkability, neighbourliness, human scale and shared enjoyment of its places (Figure 2). The Skygarden is one of the more eye-catching examples of several initiatives promoted by the first holder of this job, Seung H-Sang, and his successor

and ally Young Joon Kim.

The ambitious mayor of a big city backs a project to put a garden on a bridge. The mayor's works programme aims to redress the balance. His successive chief architects have aimed to make the city more pedestrian-friendly and where possible to adapt the existing fabric rather than erase it in favour of grand new structures. "Revitalisation" rather than "reconstruction" is how Seung H-sang puts it. The city government is also considering the introduction of a congestion charge for the historic centre of the city.

\section{3 "Moscow sky" project}

This project was designed by Moscow based landscape architectural practice "Ilya Mochalov and Partners" in 2016 as a design concept proposed to the city department of Nature uses and environmental protection. The idea was to use the upper level of the shops (stylobate), which were built in New Arbat Avenue (former prospect Kaliningrad) in early 1960. There was a special technical survey carried out to find out the structural possibilities for the buildings to carry the additional weight of the newly designed green space. The survey shoved that the buildings are perfectly all right and the design was proposed. The idea of the design was to use the former grids and foot-prints of buildings and roads which were in this place before the great demolition in 1963. The liner park on the roof was called "Moscow sky" to reflect the idea that the gardens are raised in the sky. The park offers all 
the recreational facilities such as kids play areas, sports, boardwalks and of course night time lightning. Several escalators take people from the ground level on the top of the roof and back. Hopefully this design is realised at some near future. This will bring another dimension to the city landscape and provide another sustainable landscape in the sky.

\section{Conclusion}

Typically full of people, Urban Linear high-raised Parks rarely evidence public safety concerns. An exception emerged from Wilmington, DE's linear park planning where transformation from a largely abandoned riverfront to residential, retail and entertainment produced a Business Improvement District (BID) that organized and financed uniformed security personnel and cleaning up after the crowds.

Urban Linear Parks appeal to people as public facilities with an abundance of engaging things to do and see. They produce urban places where people want to be active.

To be successful, Urban Linear high-raised parks must:

1. Exist in high density places with ready access on foot and via transit-real urban places;

2. Be both attractive and interesting, offering changing views.

3. Be wide enough to safely accommodate bikers and pedestrians, where both are expected.

4.Provide opportunities to purchase food and pleasant places to take occasional breaks.

5 . Be at least a half-kilometre long.

\section{References}

1. V.I. Telichenko, V.M. Roitman, A.A. Benuzh, Integrated safety in construction (MISIMGSU, 2015)

2. V.I. Telichenko, A.A. Benuzh, Ind. and Civ. Eng. 10, 40 (2014)

3. V.I. Telichenko, A.A. Benuzh, Adv. Mat. Res., 1065-1069, 2169 (2015)

4. A.A. Benuzh, E.N. Orenburova, Housing construction 2, 14 (2015)

5. B. Cayce, Y. Chia-Hui, UTSOA (2009) 